\title{
PerPetual StRIFE to ReARTICULATE DisCOURSE, MEANING, AND IDENTITY IN GORDIMER'S JULY'S PEOPLE: A DISCOURSE ANALYSIS
}

\author{
Hanieh MehrMotlagh, University of Tehran, mehrmotlagh@ut.ac.ir \\ Maryam Soltan Beyad, University of Tehran, msbeyad@ut.ac.ir
}

10.31902/fll.25.2018.7

UDK 81'42

\begin{abstract}
Apstract: Specific utilizations of language have the capacity to fabricate power positions for individuals or to locate them in peripheral positions. It is through on-going discursive practices that different discourses strive to foreground themselves and marginalize antagonistic discourses. As the process perpetuates, each discourse configures a particular identity and objectivity the sustainability of which depends on constant rearticulations of major concepts and preserving the previously settled meanings in a corresponding discourse. Nadine Gordimer's July's People (1981) recounts the story of characters who are obliged to cope with identity crisis and uncertainty induced out of an envisioned end of apartheid. Pertaining to Laclau and Mouffe's discourse theories, the present study reveals that the characters' identities are shaped with regard to the sub-discourses of white, black, consumerism, materialism, patriarchy, and subjugated women. Discovering the orders of discourses in the novel renders that the discursive practices of the characters, the dichotomies in their identities, and the clashes in family structures are rooted in the struggles between major discourses of white and black, traditional and modern, as well as indigenous and foreign which have created divisions in the South African society. Finally, this study sheds light on understanding how the relations among discursive practices in a fictional text are associated with the conflicts among major discourses in the society.
\end{abstract} marginalize.

Keywords: discourse analysis; identity; power; foreground;

\section{Introduction}

Identity formation in an individual, family, social class and society depends on so many factors such as time and place as well as the special modes of the construction of meaning and discourse. While major discourses construct and are constructed via social and political circumstances in a society and provide social, political, and cultural identities, there are sub-discourses which formulate an individual's personality and identity. Regarding literary works which are the reflections of crucial social and political incidents of their 
contemporary era, Nadine Gordimer (1923-2014)'s July's People (1981) is a depiction of historical upheavals and discursive interactions between the blacks and whites as the dominant discourses to envision a future for $S A^{1}$. But are the black and the white the only grand discourses which have resulted in clashes in South African society? How does a novel represent dominant discourses and sub-discourses in a society? How are discursive conflicts portrayals of the characters' identities? A study can arrive at a better understanding of orders of sub-discourses in a novel and its association with major discourses in actual society through research which initializes with explorations of personal identities and moves towards larger social domains.

Scrutinizing $J P^{2}$ with regard to Laclau and Mouffe's notions in discourse theories, this study intends to explore the overlooked aspects of formation of identity and meaning in the story. Likewise, an efficient method of analysis is used to shed light on signifying systems and discursive practices in the construction of significations in a literary text.

\section{Nadine Gordimer's July's People in Literature}

The implication of intense racial segregation in SA formed a social and political system called apartheid (1948-1994). During this distressful time, Nadine Gordimer produced fictional works reflecting the Afrikaner and the indigenous South African lives under the influence of strict racial divisions, thus her works have been widely criticized.

As individuals' identities are under perpetual reconstruction due to encountering pleasant and unpleasant experiences throughout their lives, identity loss and identity recuperations are among the frequently discussed issues by researchers with a wide range of perspectives. For instance, as the emerged disturbances in JP are due to the disruption of hierarchies between the whites and blacks as well as between the genders, Clingman has focused on the main female character who escapes from being entrapped in uncertainty induced out of demolition of the past and the absence of beginning a new phase (203). He views JP as a representation of history of SA based on which there have been historical divisions and a sense of living in between-ness (Clingman 193).

\footnotetext{
${ }^{1}$ South Africa

${ }^{2}$ July's People
} 
The issue of political reversal has been discussed by Bodenheimer who focuses on the formation of identity based on "economic facts of ownership and dispossession" (108). Bodenheimer explicates the implications of ownership, theft, possessions, and garbage to argue how the identities of the black and white characters have been framed as a result of losing or achieving properties. While Bodenheimer ends her discussion with a crucial role of objects in the world of JP, J. Newman begins her argumentations in her study by asserting a solution to the materialistic discriminations. Quoting from Gordimer's essay "Apprentices from Freedom", Newman points out that "racial problems, both material and spiritual, are hoped to be solved only in circumstances of equal opportunity" (85). Thus she focuses on the white family's realization of their dependence on economic factors and studies their loss of identity in a new economic context. Jeffrey Folks likewise puts emphasis on ownership and the reversal of political power in JP. He accounts for the relations between the main female character and the novelist which makes the study different from the previous ones.

Regarding other thematic aspects that have been scrutinized by the researchers in $J P$, Smith highlights the shattered relations between white masters and black servants. He argues that the "failure of communication" between the blacks and whites is one of the key themes in Gordimer's novels (107). The present paper, additionally, discusses the lack of communication in a white and a black family to render it as a supplemental factor to the loss of identity and meaning in the story. Likewise, while the present paper sheds light on power transitions during discursive struggles to reveal various dominant and subservient discourses, Smith in his research states that the Smales "are seen as white" (Smith 103) and July has accepted their mastery (Smith 105). Based on Smith's view, the attained superiority of the whites seems to be unaltered. But a more detailed scrutiny of the novel with respect to the characters' discursive practices and the utilized strategies uncovers the operations of sub-discourses in the story.

Besides thematic investigations of $J P$, it is vital to review the scholarly application of specific methods. As the black South Africans have been long colonized due to slavery and apartheid, the termination of racial segregation would provide postcolonial conditions. Sahlin surveys the novel from colonial and postcolonial perspectives with a focus on Husserl's ideas in phenomenology and on Ahmed's idea of "whiteness ... as a bad habit, which becomes a 
background to social action" (149). Indeed, he regards whiteness as a hegemonic formation in the novel.

In another postcolonial reading of $J P$, Tecucianu approaches Gordimer's selected novels to argue identity and hybridity with regard to Bhabha's terminologies. Tecucianu believes that Gordimer's characters reconstruct their identities in pristine circumstances (3). In comparison with previous discussed studies, Tecucianu asserts that in $J P$ Gordimer does not praise or condemn a particular ideology, and she leaves it to the readers to decide (7). Nevertheless it is crucial for a sophisticated reader to uncover the clandestine interactions among sub-discourses in a fabricated society of a novel which is a reflection of a writer's society.

\section{Method and Design}

The Argentinean political theorist, Ernesto Laclau (1935-2014) developed post-Marxist theories in collaboration with Chantal Mouffe (1943-), the Belgian political theorist. Their theories, which have been elaborated in their key work Hegemony and Socialist Strategy (1985), have been mostly employed in discursive practices associated with social and political issues, and this study is an attempt to apply their notions to the fabricated society of a literary text. Unlike many approaches in linguistics which analyze grammar and various processes of sentence production, discourse analysis often emphasizes general utilization of language among individuals or groups.

What has made discourse analysis a very stimulating topic for a large number of scholars and researchers is that the individuals in everyday conversations reveal their social class, thoughts, and personalities which reflect their identities and their power in reformulating the course of smaller social and political relations in their own favors. That is why Jorgenson and Phillips assert that the individual's ways of talking both shape and is shaped by their "world, identities and social relations" (1). This paper focuses on Laclau and Mouffe's discourse theories to scrutinize the formation of the characters' identity and power as they are involved in discursive struggles.

Based on Laclau and Mouffe's notions, similar to a sign which gains meaning through its relation to other signs in a language, social actions acquire significations with regard to their differences and associations with other actions, as Jorgenson and Phillips affirm (35$36)$, thus all social phenomena such as "economy, the infrastructure, and institutions" are discursively constructed (Jorgenson\&Phillips 30). 
In Gordimer's JP, the Smales' compulsory journey to a village acquires its meaning through its difference from Bam's business trip to Buenos Aires (55) which has a determining impact on the configuration of his identity and power. Hence social and political actions and reactions of individuals in real or fictional social circumstances achieve their meanings by the differences with those of other individuals. The produced meanings have crucial roles in assessing the quality of power relations in discursive conflicts.

The next section will shed more light on the exploration of the personalities as well as the identities of main characters in JP through Textual $^{3}$ and Contextual analyses. The Textual analysis is concerned with discovering the identities of the characters, families, and social classes to illuminate the orders of sub-discourse in the novel. Indeed, it is through the main characters' utilization of language and their specific constructed identity that the orders of discourses in the society of the novel are revealed.

Subsequently a Contextual analysis is required to associate the findings associated with a literary text to the actual society. This step provides a better comprehension of the conflicts between discourses that have been striving to attain a foregrounded locus during the related significant historical incidents of the era in SA. In both steps while exploring Laclau and Mouffe's key concepts including nodal points, moments, elements, chain of equivalence and difference, antagonisms, and dislocations, the researchers study the formation or loss of identities with regard to discursive practices.

\section{In Search of Personal Identities}

In JP there are three main characters, Maureen, July, and Bamford whose actions, thoughts, and speeches have fundamental roles in conveying Gordimer's thoughts and standpoints regarding her society. The minor characters including Maureen's children, July's wife, and the Chief share supplementary functions in portraying the identities of the blacks and the whites. Laclau and Mouffe believe that "man is the fundamental nodal point" (117) or a "master-signifier" with a partially fixed signification that determines social practices and the process of identification of the subjects in hegemonic articulations (Laclau\&Mouffe $\mathrm{xi}^{\text {) }}$ Thus each character in the novel is treated as a

\footnotetext{
${ }^{3}$ A three-step-model, including Textual, Intertextual, and Contextual analyses, has been primarily propounded by Soltani in "Discourse-Semiotic Analysis of a Separation" to have a discourse analysis of a Persian movie.
} 
nodal point that attempts to hold appropriate signifiers called "value signifiers" around the central axis to provide the desired meanings. Here a value signifier denotes any kind of sign such as type of clothes, language, action, and so on that assist the reader to recognize a particular type of personality and identity as Soltani states ("Discourse Semiotic Analysis of a Separation" 53). Since personal identities are constitutive of the characteristics of a family and their social class, the identities of units larger than an individual have shared characteristics.

Primarily $J P$ is textually explored to gather the value signifiers associated with main characters. Upon discovering the types of personality and identity of the characters, they are portrayed in some figures to provide clear and comprehensive findings. As the second step, the identities of the families and social classes are explored with regard to the accumulated attributes of the contributing members. In the final sub-step, the orders of discourses including all the competing sub-discourse in smaller society of the novels are discovered. Hence the process of the formation of identity and power is not only revealed, but the discursive conflicts among sub-discourses in the smaller society of the novel are also presented.

Maureen, whose perspectives concerning the circumstances and different events in the novel are often more distinguished in comparison with other characters, is regarded as the first nodal point. Table 1 in APPENDIX A illustrates the prominent value signifiers which provide information about her identity in JP. The significations of the value signifiers in the very table render Maureen's personality and identity. Based on Laclau and Mouffe's terminology, a sign in a discourse can be either in a form of an "element" whose meaning has not yet been fixed or a "moment" which has gained a fixed signification, since it has gone through the articulation process, and consequently the sign has gained a "closure" (105). Viewing Maureen's nodal point with regard to Laclau and Mouffe's terminologies, it is revealed that she has long preserved some value signifiers as "moments" whose meanings have been fixed around the central axis (105). However, the compulsory movement from the suburbs to a village has resulted in dislocations in Maureen's nodal point, since there are new norms or "elements" with unfixed significations (Laclau\&Mouffe 105) that bear oppositional meanings for her.

According to Laclau and Mouffe, oppositional significations and antagonisms emerge where there is an interruption in the fixed meanings (124). As Laclau explicates, to stabilize the emerged dislocations, the center must be rearticulated before other centers arise (New Reflections 40). Since the arrival of oppositional discourses 
is regarded as a threat to the position of nodal point, Maureen's identity is reformulated to be in line with new circumstances; however, there are consequential dichotomies in her personality.

Concerning the setting in the text, the value signifiers of the story have been divided into those in the city (the past) and those in the village (the present) which are fundamental in the creation of the first major dichotomy in Maureen's personality. While she was a superior white as well as a responsible mother and wife in the suburbs, she becomes inferior and submissive in the village. Her irresponsibility is revealed in her final running towards the helicopter sound; moreover, the issues of past/present and here/there have been constantly mentioned by Maureen during the course of the story.

The second dichotomy is associated with the differences between the norms of suburban and village life which have resulted in disorder and identity crisis in Maureen. Having been "born white pariah dogs in a black continent" (JP 8), she had long been regarded as a foreigner and a superior white. Thus it is significant to discuss the chain of equivalence that Maureen constructed around her nodal point. Laclau and Mouffe introduce the logic of equivalence and difference which are in association with the concept of antagonisms. Based on this logic, dominant forces create deploy "a chain of equivalent" identities to confront threatening elements with dissimilar identities (127). Being a white upper middle class for Maureen was equal to white authority, and having an economically secure life different from a black servant's chain of equivalence. Consequently, based on the logic that being white meant being something which a black was not, Maureen had constructed a specific identity for her own self.

The African traditional life strips Maureen of her previous higher locus to the extent that it alters Maureen from being responsible to irresponsible as she runs away from her undesired life and family. Based on the logic of equivalence, a village life is equal to living in mud huts, working on lands, speaking African, and eating African food. Maureen's nodal point that once used to occupy the dominant position in comparison with that of their servants, falls into a subordinate locus, as she arrives at an understanding of her family's dependency "on these people"(JP 33). Thus due to the compulsory journey to the black African village, Maureen's previously constructed chain of equivalence and identity are also altered, yet she is not totally devastated. Although she had the suburban norms being sedimented in her discourse in the city, she gradually rearticulates fundamental concepts to find a locus as a woman if not as a dominant 
mother/wife/master in current circumstances. These rearticulations lead to the initiation of some processes in Maureen's identity.

The journey to July's village initializes the process of disposition comprising the loss of material properties and spiritual belongings which includes superiority and mastery. This process is led to two other processes of inferiority and pragmatism which have dire consequences for her identity and fate. Indeed, Maureen constructed her chain of equivalence in line with the sub-discourses of white and materialism, yet as mastery and ownership lose their meanings, the sub-discourses are dislocated as well. Her dependency on actual properties is more illuminated in her frequent references to the presence and absence of their vehicle while living in the village. As the loss of ownership makes her reach the state of nothingness, she feels that "she was already not what she was" (JP 35).

The deprivation of Maureen's spiritual belonging is associated with the lack of communication with her husband and the villagers as well which deteriorates the state of her identity crisis and locates her in an inferior position. As her loss of belongings goes by, Maureen admits her family's total dependency on July. Indeed, Maureen has constructed her chain of equivalence in line with sub-discourse of materialism, yet, as ownership and possession lose their meanings, the sub-discourse is deprived of its power.

After referring to the signs and their significations in Table 1 in APPENDIX $A$, the next process in which Maureen's personality is involved is awakening pragmatism, as she has to come up with the norms of African traditional life. Des Jardins affirms that there are two different outlooks towards pragmatism. First, a pragmatist does not look for ideals; he/she believes in what is achievable. Second, pragmatism is associated with the practical aspect of truth which is attestable in experience (259). Although Maureen is stricken with dependency and dispossession, she is not hindered from doing what is practical in adapting herself to the new circumstances, while Caminero-Santangelo believes that Maureen is unable to align her identity to the new circumstances (107). The more she adapts herself to the new situation, the more she adopts pragmatism and a hopeless outlook towards her life concerning the impossibility of regaining her losses. Her utmost pragmatic outlook lies in her final escape from nothingness, inferiority and responsibilities, since it is the only achievable goal for her. Maureen's nodal point has been rendered in Figure 1 in APPENDIX B. 
Due to the discursive struggles between Maureen and July ${ }^{4}$, he is regarded as the next significant character. Based on the obtained information from the available value signifiers concerning July's speeches, behaviors, and interactions with other characters, his nodal point has been articulated with fundamental moments including being a member of working class, inferior, patriarchal, moral and ethical; being a thief; becoming superior; having Machiavellian traits; valuing Africans traditional culture; valuing modern suburban norms; and being under the influence of the naturalized white superiority.

Being a submissive servant from an inferior locus, July has been well aware of the polarized relationships between the blacks and whites for a long time, since from the exposition of the story he mentions the master/slaves relations between his/their kinds. The idea of polarization by the discourses has been clarified by Soltani suggesting that this social division is also echoed in the individual's conducts and actions, as the subject's thoughts are formulated with regard to a "us-them" standpoint. In various discourses "us" is foregrounded and "them" is marginalized to provide a central powerful locus via defining specific significations in discursive conflicts. The application of such strategies as foregrounding precise significations and the marginalization of certain other different meanings would hegemonize a discourse whose power will be sustained through covert naturalization of specific types of power (Power, Discourse, and Language 112). In this case, the white discourse was foregrounded and hegemonized in the suburbs. Likewise, the black discourse was marginalized to guarantee the continuation of the white's power.

During the hegemony of the white discourse, the black discourse was marginalized to hinder its attainment of a stable meaning. Laclau and Mouffe point out that other possible meanings are eradicated in order to sustain the present power by being sent to the "field of discursivity" (112) where they anticipate a proper instant to come forth to the center. Any occurrence of dislocations in the previously sedimented discourse would provide opportunities for peripheral discourses to surface with their new elements. In the meantime, the previously moulded identities undergo alterations and dichotomies due to the emergence of new concepts around the nodal

\footnotetext{
${ }^{4}$ Due to space limitations, the tables for other characters have not been included in this paper. The complete tables have been rendered in MehrMotlagh's Discursive Struggles over Construction of Power and Identity in Selected Novels of Andre Brink and Nadine Gordimer (PhD thesis, University of Tehran, 2017).
} 
point. Quite in the same manner, July as a nodal point employs the emerged dislocations in the white discourse in the village to establish his concepts and significations. Thus he gradually renders the signs of four distinct dichotomies in his identity.

The first contradiction is due to the reconstruction of the chain of equivalence with regard to the past and present circumstances. While July used to be a submissive inferior servant in the suburbs, he is now a superior master who makes decisions in the village. Similar to Maureen, July repeatedly contrasts the white life with the black life through so many references. The second dichotomy is concerned with the residual signs of being at the service of the whites while attaining a superior position in the village. This is rooted in both his ethical and moral standpoints and the power of the naturalized dominance of the white discourse which has managed to articulate itself in a temporal firm locus. As Laclau and Mouffe affirm, the "logic of hegemony" also governs the "identity of the hegemonic subject" (85). In other words, as the superiority of the whites has been hegemonized for July, he has approved the logic of difference based on which he is something which the whites are not.

The third dichotomy in July's identity is associated with his morality and ethics which are in contrast with the signs of immorality in him. July's morality comes short when the lack of possession is at work. During the course of the story, he is rendered as a thief and a Machiavellian. As Erritouni remarks, his actions concerning the vehicle have been an attempt to theft (58). Also July does not inform the Smales of the Chief's law concerning vising him to take permissions, since he was intending to preserve the white's total dependence on his power as well as pursuing being paid for his services by the Smales. In giving response to Maureen's indictment on not telling the white family to visit the Chief sooner, July only claims that "now, I'm tell you" (JP 122) and later he postpones the time of the visit. Indeed, he schemes for achieving possessions and dominance, no matter by whose losses his present locus is coming forth.

The fourth dichotomy is concerned with the differences between what is rural and what is suburban. July opts to preserve some norms such as patriarchy in village life and culture, as his wife and mother's approval of "his dictum... without argument" (JP 22) is the portrayal of women's submissiveness to male dominance. But he also values white style of life, driving, and modern medicine as the signs of white suburban norms. It is worth noting that July's criticism of the Chief is indeed a sign of disvaluing their traditional authority. He claims that the Chief is a poor man who is not able to cope with the 
freedom fighters physically and economically (JP 149). Significantly here July's discourse has the potential to function as antagonism to the hegemony of African traditional leadership. Following Laclau and Mouffe's notions, social antagonisms are parts of the field of discursivity (ix) where the contingent discourses with possible meanings anticipate the right moment to come forth. In this case, July's silence in presenting the whites to the Chief and his critical views of the authority make him a potential internal antagonistic force whose discourse is floating in the field of discursivity.

Being Maureen's foil, July undergoes the process of superiority as a result of the blacks' uprising against apartheid which created dislocations in the sedimented discourse of the whites. Thus he gradually attempts to articulate new significations around his nodal point. He obtains the power not only from the sedimented subdiscourse of patriarchy in his traditional village, but he also functions as the white's master and superior via functioning as their provider and sources of indigenous knowledge. Thus such pristine concepts as being superior and master are being constructed as moments for the black's master signifier in discursive relations with the white discourse.

Despite political transformations in favor of the blacks in the story, the problem of lack of communication is observed in July's family too. July used to meet his family every two years (JP 163) and his wife does not know how to have a conversation instead of writing letters to her husband (100). Moreover, they have oppositional perspectives on their lives in future. While July's desire is to go back to the city and live there with his family (163), his wife wishes their family "get more lands ...grow more mealies ... [buy] a tractor to plough ... have a shop here, [and] sell soap and matches, sugar]" (164). While working on land and production of Mealie as African traditions are indispensable parts of her chain of equivalence, July values modern suburban life and possessions such as a room for oneself, a machine to wash the clothes, and a room for bath (26) which have been constructed in his chain of equivalence after fourteen years of living in the suburbs. Consequently, the dichotomies in their constructed identities and the lack of communication do not guarantee the unity and solidity of their nuclear family.

\section{The Employment of Soft Strategies in Discursive Struggles between Maureen and July}

While July gradually articulates dominance for his nodal point in the village, Maureen's discourse and her attempts to re-establish her authority function as an antagonistic force which endangers July's 
power. Laclau asserts that the dominant discourse would subordinate or eliminate opposing discourses because any disturbances to the already fixed significations for the central discourse would result in an impure identity (Emancipation(s) 29). This is why Maureen strives to re-hegemonize her discourse through utilizing policies while taking part in discursive struggles with other discourses. According to Soltani, foregrounding and marginalization, as the two prominent policies in treating antagonistic discourses, are employed both by the central discourses in larger social spheres and the subjects in smaller social domains via utilizing soft and hard strategies (Power, Discourse, and Language 112-113). Maureen endeavors to resuscitate her dominant locus through utilizing particular language as a soft strategy in dealing with July's discursive tactics.

Among discursive conflicts between Maureen and July, one instance has been depicted to discuss the employed strategies. Here the oscillation between their dominance is illuminated, while they both are attempting to make use of language as a soft strategy to cope with each other. Talking about the village women that must find food, July ambiguously mentions that "this is their place" (JP 117) which warns Maureen as it marginalizes her discourse in two ways. Either it means their "role" (117) as food finders in an inferior locus in a patriarchal community, or it signifies their "earth" (117) and home. In both cases it provides a downgrading position for Maureen. Thus she attempts to defy July's downgrading discourse (Note: The significations associated with signs and value signifiers in the character's speeches and reactions have been provided within the brackets):

[Maureen] spoke with the sudden changed tone of one who has made a discovery of her own and is about to act on it. - l like to be with other women sometimes... I've found out Martha does understand-a little Afrikaans, not English. [She is challenging July's speech through words and change of tone]

He settled stockily on his legs. - It's no good for you to go out there with the women. [He is asserting his notions through his solid gesture and words. The locus of July's master signifier is disrupted]

[Maureen:] Are you afraid I'm going to tell her something? [Maureen is rhetorically threatening July.]

Giddied, he gave up a moment's purchase of ground. -What you can tell? - His anger struck him in the eyes. [His anger indicates his threatened power position] -That I'm work for you fifteen years. That you satisfy with me. [He is justifying his dignity and asserting his right 
deeds] - The cicadas sang between them. Before her, he brought his right fist down on his breast. She felt the thud as fear in her own (JP 117-119). [July's nodal point regains a firm status via a fierce physical reaction which frightens Maureen]

The above discursive conflict is over with Maureen's silence, since "she had never been afraid of a man" (JP 119) In fact her fear sends her antagonistic discourse to the field of discursivity. In this example July utilizes downgrading, asserting, justifying language as soft strategies. For so many years, the marginalized discourse has been that of July. Here it is Maureen's discourse which has been silenced and sent to a peripheral locus by July's final physical threatening reaction. In the past, being a black equalled a chain of equivalence that included being a servant, subordinate, dependent, and having no possessions. Now it equals being superior, independent, and a decision maker. This modification also occurs in Maureen's chain of equivalence which contains being inferior, dependable, and dominated and having no possession.

There are other instances of discursive struggles between Maureen and July during the course of the story where Maureen strives to foreground her discourse to gain dominance. In most cases she employs soft strategies including accusing, humiliating, downgrading, persuading, and rationalizing languages to renovate her superior position and simultaneously represent herself as a power seeker. Almost in all conflicts she is silenced or her power is neutralized and sustained in the field of discursivity, since the black discourse with its major concepts resides in the central locus at present.

The third prominent character and nodal point in the story is Bamford Smales. Being a descendant from his Boer ancestors, Bam is in part a foreigner in comparison with July as an indigenous South African. The word "Boer", according to Robinson, means a farmer in "Dutch and Afrikaans". Dutch settlers [or Afrikaners] who immigrated to SA in the $17^{\text {th }}$ and $18^{\text {th }}$ centuries (11) were called Boers. Bam and his family are also regarded as foreigners in July's village, due to the differences regarding discourse and their specific constructed chain of equivalence. Noticeable value signifiers associated with Bam's words and interactions in $J P$ have the following significations that define his identity: a member of upper middle class; a superior white in the suburbs: loving SA while living in the suburbs; being materialistic and consumerist; being moral and ethical; being inferior, dispossessed, and adaptable; and getting effeminized in the village.

Similar to Maureen, Bam's obligatory journey to the village results in many alterations in his personality and behavior with 
consequential impacts on the emergence of three distinct dichotomies in his identity. The first dichotomy is associated with the oppositions that have been induced out of the life circumstances in the past and present. Bam's identity is under the impact of his life in the past while he was a master and superior in the city and as a dispossessed inferior in the village at present.

The second dichotomy is associated with his love of SA. Not running away from the country during the city riots reveals Bam's patriotism, yet moving into July's village functions as a turning point in his personality and thoughts, where he becomes uncertain about his past determinations and love of the country, due to their present inferior circumstances. While Maureen affirms that they have "stayed and lived the best" they could, Bam remarks that "god knows, look at us now" (JP 55).

The third dichotomy in Bam's identity is due to the articulated oppositional moments in the chains of equivalence of discourse of modern suburban life and discourse of African traditional life. The former, once equaled city life, modern academic knowledge, possessions, civilization, superiority, and secured economy. Now the latter equals village life, mud huts, knowledge of nature, no possessions, nature as a source of food, and patriarchy. Bam who was a superior master, becomes inferior through losing his vehicle and gun as the remaining possessions and his academic knowledge are not much useful in rural areas.

Analogous to Maureen, Bam enters the inferiority and dispossession processes as his nodal point is disturbed with uncertainty and loss of power. His inability to understand the language of the black is one of the factors in losing his power in chapter six, since he cannot understand the "anecdote that obviously referred" to him while he keeps the company of the black (JP 21) According to Foucault's insight on knowledge and power, such factors as social, political, and economic relations form the very knowledge and truth (Foucault et. al. 86). Thus Bam's lack of knowledge of African language deteriorates his position as July's white dominant employer. His reaction to this situation is merely a pleasant expression on his face which is equal to silence. Foucault believes that "silence and secrecy" can either reinforce power or diminish its control (101). Here Bam's silence renders his impotency to take an efficient part in the discursive social relations among July's people.

In contrast with Maureen, the emerged transformations do not end in Bam's annihilation. His ability to adapt himself to new circumstances is analogous to his ability to modify the moments in his 
chain of equivalence which is a noteworthy issue in recuperating his identity. Although the loss of control over his vehicle denotes his dispossession and loss of power, after a while he assigns a function for himself and becomes a "provider of meat" (JP 94). The meat provider is a new moment which is added to his chain of equivalence in order to be in line with chain of equivalence of the black discourse in the village.

There are other instances in which Bam's involvement in discursive struggles with the Chief as an indigenous South African character signals the impending deconstruction of his dominant white discourse. Thus it is significant to contemplate on the power shifts between Bam and the Chief as it has been provided in APPENDIX C for more illuminations. Finally, total deconstruction of Bam's once dominant discourse is revealed in his de-feminisation at the end of the novel where he does not look for the lost gun; rather he stays in the hut and prepares the food (JP 188). Here the process of adaptation with its healing effect is at work as well, since Bam's ability to reformulate new moments function as a significant factor for him to survive the loss of power and identity crisis. Going fishing at the end of the novel (JP 191) is the epitomization of his adaptable identity.

The exploration of the personal identities unveils that almost all characters experience changes and dichotomies in their identities. Both Maureen and July are power seekers and attempt to attain a firm stature for their discourse by foregrounding their desired significations and via marginalizing the opposing discourse. Bam takes part in the discursive conflicts; however, he is frequently silenced since he is not a pursuer of power. Due to the emergence of transformations that result in identity crisis and uncertainty for Maureen and Bam, their middle class family loses its previous homogenous structure. While the failure of communication perpetually grows, increasing incongruities between Maureen and Bam, demolishes a nuclear family configuration. The lack of mutual communications is apparent in July's working class family as well, since there are discrepancies between July's and his wife's perspectives towards values of traditional and modern lives. It is worth noting that the family structure has the potentials to be preserved through hegemonic intervention of July's patriarchy as a sedimented discourse in their traditional life.

\section{Orders of Discourses in the Society of July's People}

While the previous sections analyzed the personal identities through available signs and their significations, this section deals with the orders of discourses which are concerned with all the discourses 
that take part in discursive challenges to stabilize their desired meanings in one domain, as Jorgenson and Phillips state (141). Based on the obtained significations, the South African society of the novel includes the following six oppositional sub-discourses which strive to articulate meaning through discursive struggles: Sub-discourse of the whites represented by the Smales, Sub-discourse of the blacks rendered by July and his people, Sub-discourse of African traditional life and culture revealed via the villagers and July's family, Subdiscourse of suburban Afrikaners' modern life and culture represented by the Smales, Sub-discourse of patriarchy in the African village, and Sub-discourse of submissive black women represented by July's wife and mother.

In discussing the orders of discourses, Jorgenson and Phillips argue that it is a system which "shapes and is shaped by specific instances of language use", since the subjects might restructure this system either through bringing in new discourses from other orders, or via altering the same order of discourse (72). Thus the more an order of discourse is unalterable in the course of time, the more the dominant discourses are being sedimented in a social and political context. As a result of the portrayed upheavals in $J P$ and with regard to the discovered orders of discourses, the sub-discourses of patriarchy, submissive black women, African traditional life and culture have had the lowest amount of crisis in identity and power, despite the presence of argued dichotomies.

The issue of power and its preservation depends on the vigor and locus of associated concepts that have been articulated in a discourse. In $J P$, the white discourse in the suburbs attains its power from possessions and white hegemony as its sedimented articulated moments. The source of power of black discourse in the village is the indigenous knowledge and patriarchal hegemony that have been constructed as significant moments. A black discourse in the suburbs and the white discourse in the rural area are struck with dislocations of their fundamental concepts and their previously defined functions. Consequently, the continuation of power of each discourse depends on the structure of hegemony and the rearticulations of concepts in new circumstances.

\section{Contextual Analysis: The Associated Social and Political Upheavals}

$J P$ was written in 1981 when SA was racially segregated under apartheid system for thirty-three years. The novel is set at a time in 
future and illustrates the perspectives of a community under the apartheid regime and envisions the future of SA and how apartheid is abolished. The novel was concurrent with political and social upheavals of the 1960s and 1970s including many internal crises such as Africanist movements, strikes, and protests. As the final step in the present study, the researchers pursue the roots of the discovered subdiscourses in a larger social and political domain.

Before the arrival of the foreigners in $17^{\text {th }}$ century, SA with its tribes and traditional leadership was dominated by the discourses of the blacks and indigenous tradition. Based on Thompson's elaboration, most South African tribes were managed through Chiefdom (14) and their economy was via "agriculture, pastoralism, and metallurgy" (16). Their communities were highly hierarchical, as "men controlled women, elders controlled youths, patrons controlled clients, and ... chiefs controlled commoners" (Thompson 23). However, the entry of the Dutch traders and settlers had impacts on the emergence of modernity in SA, as Thompson states (33). Subsequently, in the next two centuries, upon the arrival of Western codes and values as a grand discourse in SA, such sub-discourses as white imperial dominance, Christian religion, and Capitalism were transferred into a traditional society. Regarding the traditional SA, Philip remarks that:

While our missionaries ....are everywhere scattering the seeds of civilization ... they are extending British interests, British influence and the British Empire.... Wherever the missionary places his standard among a savage tribe, their prejudices against the colonial government give way, their dependence upon the colony is increased by the creation of artificial wants...Industry, trade and agriculture spring up...they are the triumph of ... civilization over barbarism. (pp.ix-x)

Pondering upon this statement, Majeke holds that traditional tribes have been destroyed for the sake of a "Christian capitalist civilization" (1). Similarly, the South African men in JP have been obliged to work in gold mines where the discourses of modernity and capitalism preside, while the Chief cherishes the preservation of the discourse of tradition and the purity of his tribe. Thus, the indigenous tradition, culture, and values have been long involved in discursive struggles with the discourse of modernity which has been represented by the foreign forces including Afrikaners, the British, and missionaries, as the historical evidences attest.

The power of Great Britain in SA has had political, economic, and cultural impacts on both South African residents and Dutch settlers. Worger and Byrns affirm that as Britain was expanding its 
territory in the $20^{\text {th }}$ century, it excluded South African workers through a variety of bigoted laws including "pass laws, urban ghettos, impoverished rural homelands, [and] African migrant labour" during industrial revolutions (I-li). Huber believes that the British also dominated the Dutch due to their supposedly ineptness in governing their interests in the country (11). Thus Britain as an external antagonism attempted to foreground itself via defining the Africans as being inferior and the Afrikaners as being in need of government to hegemonize their superiority.

Huber points out that gradually Afrikaners opt to attain a distinct pure position via separating themselves from the British power and the Africans. They attempted to provide distinct religious, political, and economic institutions among themselves. Finally the excess of desire for isolation ended up in assigning apartheid in 1948 to preserve Afrikaner culture, language, and nationalism (15-16). In dealing with the British, they succeeded in sustaining power through such soft strategies as transforming signs of cultural values such as holidays, pictures of British royals on paper money and stamps to purify their identity (as cited in Huber 17) Apartheid functioned as a systematic method in the creation of us/them polarities among the whites and blacks for 43 years. Indeed, $J P$ has been an attempt to imagine a reversed condition

There are many incidents and a number of established organizations which have been influential in the termination of apartheid that persisted almost for forty years. During the 1940s and 1950s, the black activists including Nelson Mandela and others demanded equal rights. The roots of Anti-apartheid discourse can be traced in South African universities where the formation of South African Students Organization and Black Consciousness Movement gradually rearticulated new concepts and identity for the black discourse. According to Verwey, in 1968 the South African Students Organization was formed with the purpose of discarding the concepts and codes such as "reconciliation and nonviolence" which had been suggested by the white liberals for the social and political problems between the blacks and whites (19). Indeed the transformation of concepts in a sedimented discourse has consequential dislocations and identity reformulations for the followers of the hegemonized white discourse.

As the new meanings and ideas were gaining more supporters on the side of the blacks, it resulted in Black Consciousness Movement which triggered the re-articulation of black identity in contrast with their defined inferiority. In 1971 Biko provided a comprehensive 
definition regarding Black Consciousness. He insisted that the blacks should be proud of African values and culture; they should not "regard themselves as the appendages to white society", and they must support black African communities mutually (1). This statement focuses on the significance of unity among the blacks and the independency from established whites' values. The same notion is presented in $J P$, where Bam as the writer's mouthpiece, asserts that "the whole black nation" is the Chief's nation (JP 145).

To continue with the next incident, Soweto riots in 1976 have been regarded as the hallmark of the rise of the black discourse against harsh cruelties of apartheid. Based on Crompton's explanations, upon the declaration of Afrikaans and English as the official languages of teachings, it was regarded as another oppressive strategy by the Afrikaner government. Consequently African students began a riot which had dire consequences as South African military severely suppressed the protesters (6) as a sign of hard strategies to exclude any black antagonistic anti-apartheid discourses.

Besides Gordimer's obsessions with the clashes between the discourses of black and white, she has reflected on the oppositions between tradition and modernity. This idea is observable in Lovesey's notion, as he affirms that $J P$ is an imaginary representation of the apocalypse of modernity and apartheid, since "there is an urgent need...for new structures, roles, institutions ... and language" in the novel (133). JP is the portrayal of indigenous discourse with such moments as traditional language, laws, and life style in indigenous African villages. This discourse has been long dominated and marginalized by the foreign or Afrikaner discourse. The foreign discourse is interrelated with the discourse of modernity that includes such moments as city life, materialistic culture, and so on. It is the imaginary civil war that creates dislocations for the dominance of the discourses of modernity, the whites, and the foreign in the novel.

Regarding the formation of identity in JP, both the Afrikaners and the indigenous Africans' identities undergo transformation due to the oppositions between tradition and modernity. Having been configured with regard to the values in modernity, the Afrikaners' identities are more prone to get stricken in case of the absence of the associated meanings and codes in the African village. The indigenous African identities have been constructed under the influence of African tradition and European modernity. But although the blacks have been under the dominance of consumerism, materialism, city life and culture as significant moments in modernity, they have attempted to preserve patriarchy, women's submission, and traditional village life 
and culture as moments in their black discourse. Thereby it is possible to conclude that this novel is a portrayal of survival of tradition in modernity but not vice versa.

\section{Conclusion}

By and large this study has offered a method for exploring English literary texts based on Laclau and Mouffe's theories which have been mostly employed in larger social and political domains. Having scrutinized $J P$ in a Textual analysis in smaller social domains, the researchers moved towards associating the obtained findings to the larger social sphere. In other words, the exploration, which initiated from novelistic descriptions, was supplemented by social and political clarifications to render how the fabricated and actual societies construct and are constructed through discursive challenges.

Upon discovering the orders of discourse in $J P$, it is attested that the characters' identities in smaller social spheres are formulated with regard to the defined meanings and concepts in six sub-discourses of black, white, indigenous African traditional life and culture, suburban/Afrikaners' modern life and culture, patriarchy, and submissive black women. Subsequently through a contextual analysis that refers to the associated historical incidents in the novel, the researchers argued that the prominent roots of discursive struggles both in the novel and in the society reside in clashes between the grand discourses of white and black, tradition and modernity, and indigenous and foreign which have resulted in divisions in the South African society.

\section{References:}

Biko, Bantu Stephen. "The Definition Of Black Consciousness by Bantu Stephen Biko, December 1971, South Africa." Sahistory.org.za, South African History Online, 2001.

Bodenheimer, Rosemarie. "The Interregnum of Ownership in July's People." The Later Fiction of Nadine Gordimer, edited by Bruce King, Ebook ed ed., Maemillan, 1993, pp. 108-119.

Caminero-Santangelo, Byron. African Fiction and Joseph Conrad: Reading Postcolonial Intertextuality. State University of New York Press, 2004. Google Books Search, Web Jan. 072018 from https://books.google.nl/books?id=zlvm24w8PXYC\&pg

Clingman, Stephen. Novels of Nadine Gordimer: History from the Inside. Bloomsbury Pub., 1993. PDF. 
Crompton, S. W. Desmond Tutu: Fighting Apartheid. New York: Chelsea House. 2007. Google Books Search. Web June 212017 from https://books.google.com/books?id=wllJ12oGE_IC\&pg=PA6\&d

Des Jardins, Joseph R. Environmental Ethics. 5th ed., Cengage Learning, 2012. Google Books Search. Web June 122017 from https://books.google.com/books?id=b2alDaZ87MoC\&pg

Erritouni, Ali. "Apartheid Inequality and Postapartheid Utopia in Nadine Godimer's July's People." Research in African Literatures, vol. 37, no. 4, 2006, pp. 68-84., doi:10.1353/ral.2006.0087.

Folks, Jeffrey J. "Artist in the Interregnum: Nadine Gordimer's July's People." Critique: Studies in Contemporary Fiction 39.2: 11526. 2010. PDF.

Foucault, Michel, J. D. Faubion, and R. Hurley. Power. James D. Faubion (Ed.). New Press, 2000. PDF.

Foucault, Michel. The History of Sexuality. Trans. Robert Hurley. New York: Pantheon, 1978. PDF.

Gordimer, Nadine. July's people. Electronic Edition ed. London: Bloomsbury Publishin Plc, 2012. Google Books Search. Web March 25, 2017 from https://books.google.com/books?id=z_OyrAohdEIC\&printsec

Huber, Erran Michael, "Identity Crisis: The Development of Ethnic Identities in South Africa and Northern Ireland and Resolutions to Ethnic Violence." (2013). College of Arts \& Sciences Senior Honors Theses. Paper 50. <http://doi.org/10.18297/honors/50>.

Jorgensen, Marianne, and Louise Phillips. Discourse Analysis as Theory and Method. London: Sage Publications, 2002. PDF.

Laclau, Ernesto. Emancipation(s). Verso, 1996. Google Book Search.

Web 6 Dec. 2016 from

https://books.google.com/books?id=QFwiHJP8mdUC\&printsec

---. New Reflections on the Revolution of Our Time. Routledge, Chapman \& Hall, Incorporated, 1990. PDF.

Laclau, Ernesto, and Chantal Mouffe. Hegemony and Socialist Strategy: Towards a Radical Democratic Politics. 2nd ed. London: Verso, 2001. PDF.

Landau, Paul S. Popular Politics in the History of South Africa, 14001948. Cambridge University Press, 2010. PDF.

Lovesey, Oliver. "Postcolonial Apocalypse and the Crisis of Representation in July's People." Nadine Gordimer's July's People: A Routledge Study Guide, edited by Brendon Nicholls, Taylor and Francis, 2013, pp. 130-145. Google Book Search. 
$\begin{array}{lllll}\text { Web } & 6 & \text { June } & 30 & 2017\end{array}$ https://books.google.com/books?id=dTsVAgAAQBAJ\&pg

Majeke, Nosipho. "The Role of the Missionaries in Conquest - Chapter III - Dr. Philip - 'Defendre of the Hottentots.'” Sahistory.org.za, South African History Online, 1986.

MehrMotlagh, Hanieh. Discursive Struggles over Construction of Power and Identity in Selected Novels of Nadine Gordimer and Andre Brink. Unpublished PhD Thesis. University of Tehran. Tehran. 2017. PDF.

Newman, Judie. Nadine Gordimer (Routledge Revivals). . Routledge, 2014. Google Books Search, Web March 27, 2017 from https://books.google.com/books?id=itTpAwAAQBAJ\&printsec

Philip, John. "Preface." in Researches in South Africa: Illustrating the Civil, Moral, and Religious Condition of the Native Tribes: Including Journals of the Author's Travels in the Interior. London: J. Clowes. 2009. Vii-Xxxv. Google Books Search. Web June $\quad 18 \quad 2017$ from https://books.google.com/books?id=FGZTAAAAcAAJ\&pg

Robinson, Jane Marchese. Tracing Your Boer War Ancestors: Soldiers of a Forgotten Wa. South Yorkshire: Pen and Sword, 2016. Google Books Search. Web June $14 \quad 2017$ From https://books.google.com/books?id=b_q0DQAAQBAJ\&pg

Sahlin, Tove. Interregnal Identity Processes: A Phenomenological Reading of Gordimer's July's People. Diss. U of Gävle, 2012. Diva-portal.org. Web 27 Mar. 2017.

Smith, Rowland. "Masters and Servants: Nadine Gordimer's July's People and the Themes of Her Fiction." Salmagundi, no. 62, 1984, pp. 93-107. JSTOR, JSTOR, www.jstor.org/stable/40547639

Soltani, Ali Asghar, Power, Discourse, and Language. Fourth Edition. Ney Publication, 2016. Print.

---. "Discourse Semiotic Analysis of a Separation" Social Studies 21.2 (2015): 43-72. PDF.

Tecucianu, Cătălin. "South Africa Reformed: Social Changes in Nadine Gordimer's The House Gun." International Journal of Communication Research, vol. 4, no. 3, Sept. 2014, pp. 245250. Web 27 Mar. 2017 Phdthesis.uaic.ro.

Thompson, L. M. A History of South Africa. Yale UP. 2000. PDF.

Torfing, Jacob. New theories of discourse: Laclau, Mouffe, and Zizek. Blackwell Publishers, 1999. Google Books Search. Web Feb. 21 2017 from https://books.google.com/books?id=SXVcVIhmi9wC\&dq 
Verwey, E. J. New Dictionary of South African Biography .Vol. 1. HSRC. 1995. Google Books Search. Web June 282017 from https://books.google.com/books?id=rl8nkylD3WsC\&pg

Worger, William H., and Rita M. Byrnes . "South Africa: A Country Study." South Africa: A Country Study, edited by Rita M. Byrnes, 3rd ed., Division, 1997, pp. Xlvii-Lxv. PDF.

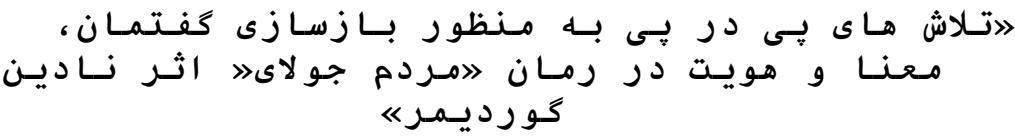

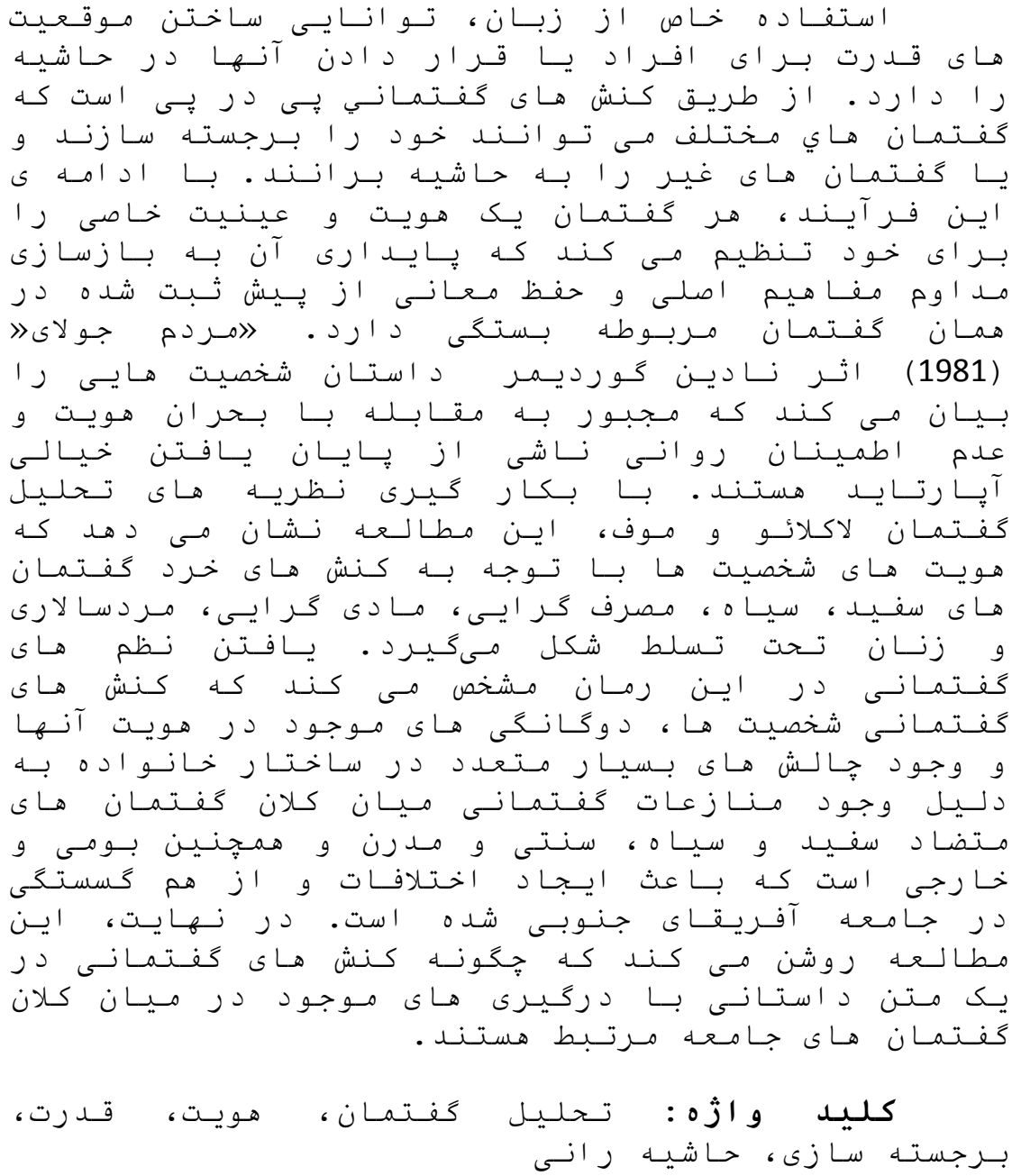




\section{APPENDIX A}

TABLE 1. The Prominent Aspects of Maureen's Personality

\begin{tabular}{|c|c|c|}
\hline 0. & Value Signifier & Signification \\
\hline & $\begin{array}{l}\text { She has lived in Johannesburg (JP 2). } \\
\text { There are two black servants in } \\
\text { Maureen's house, the "cook-nanny, Nora" } \\
\text { (11) and also July who has worked for her } \\
\text { family for "fifteen years" (85). }\end{array}$ & $\begin{array}{c}\text { A Member of Upper } \\
\text { Middle Class }\end{array}$ \\
\hline & $\begin{array}{l}\text { She observes ethics with "her smiles } \\
\text { and gestures, to convey respect" (160). } \\
\text { The servant, Lydia, used to be her "true } \\
\text { friend" (38), as there is a friendly } \\
\text { relationship between them in the fifth } \\
\text { chapter. }\end{array}$ & Moral and Ethical \\
\hline & $\begin{array}{l}\text { She rejected the white's privileges, } \\
\text { though she used to have black servants. } \\
\text { Later It is revealed that "when she } \\
\text { handed some new object on to him } \\
\text { [July] it was because ...it was because } \\
\text { she no longer valued it" (81). She } \\
\text { realizes that if she had learned an } \\
\text { African language instead of ballet (54), } \\
\text { she would not have to feel inferior to } \\
\text { the blacks. }\end{array}$ & A Hypocrite \\
\hline & $\begin{array}{l}\text { She steals malaria pills from the } \\
\text { pharmacy during the attacks by the } \\
\text { freedom fighters ( } 46) \text { for the sake of her } \\
\text { children. She insists on their hygiene as } \\
\text { "she washed the children, then herself } \\
\text { in their dirty water" (11). She supported } \\
\text { her husband's liberal thoughts through } \\
\text { rejecting their white privileges (10). She } \\
\text { used to send many gifts for July's } \\
\text { children and wife in the village (20). }\end{array}$ & $\begin{array}{c}\text { A Responsible } \\
\text { Mother, Wife, and } \\
\text { Master }\end{array}$ \\
\hline & She runs away in the final chapter (195). & $\begin{array}{c}\text { Becoming } \\
\text { Irresponsible }\end{array}$ \\
\hline & $\begin{array}{l}\text { Her marriage has been out of a } \\
\text { "contract" in return for possessions } \\
\text { without which her husband is merely }\end{array}$ & $\begin{array}{l}\text { A Materialistic, } \\
\text { Possessive, and } \\
\text { Consumerist }\end{array}$ \\
\hline
\end{tabular}




\begin{tabular}{|c|c|c|}
\hline & $\begin{array}{l}\text { "an architect lying on a bed in a mud } \\
\text { hut" (119). Nothing could satisfy her } \\
\text { and the family members "as buying } \\
\text { things" rather than "feeding rabbits" (7). } \\
\text { The presence of the vehicle functions as } \\
\text { a "distracting relief of bad news, over } \\
\text { the radio" (64). }\end{array}$ & \\
\hline & $\begin{array}{l}\text { Maureen does not know "African } \\
\text { language" (54). Having realized that her } \\
\text { family is similar to July's "cattle and } \\
\text { pigs" (117), she admits her family's total } \\
\text { dependency on July, since everything is } \\
\text { "supplied by July" (189). }\end{array}$ & $\begin{array}{c}\text { Becoming Inferior } \\
\text { and Dependent }\end{array}$ \\
\hline & $\begin{array}{l}\text { Realizing that her some of her home } \\
\text { gadgets were stolen by July, she states } \\
\text { that "honesty is how much you know } \\
\text { about anybody, that's all" (89). She } \\
\text { recognizes that learning Fanagalo, } \\
\text { instead of ballet (54), would not cause } \\
\text { her to feel inferior to the blacks. She } \\
\text { drowns some kittens "in a bucket of } \\
\text { water" (108) and justifies it as the best } \\
\text { way to have "reduction of suffering" } \\
\text { (109). She runs away from nothingness } \\
\text { in the final chapter (195). }\end{array}$ & $\begin{array}{c}\text { Entering the Process } \\
\text { of Pragmatism }\end{array}$ \\
\hline & $\begin{array}{l}\text { She prioritizes tap water over the river } \\
\text { water (17), cares for personal hygiene } \\
\text { (9), and keeps the fire off during the } \\
\text { night, since it is "unhygienic" and not } \\
\text { "civilized" (125). }\end{array}$ & $\begin{array}{l}\text { Valuing Suburban } \\
\text { Norms }\end{array}$ \\
\hline 0 & $\begin{array}{l}\text { There are "many silences between them } \\
\text { [Bam and Maureen]" (44). They quarrel } \\
\text { over Bam's not being "able to speak } \\
\text { French" (55), giving the car keys to July, } \\
\text { and deciding on running away from the } \\
\text { suburb (57). }\end{array}$ & $\begin{array}{c}\text { Suffering from Lack of } \\
\text { Communication }\end{array}$ \\
\hline 1 & $\begin{array}{l}\text { She learns how to prepare "porridge" } \\
\text { (69); washes herself under the rain } \\
\text { water (59); and helps the black women } \\
\text { in cutting the grass (159). }\end{array}$ & Partially Adaptable \\
\hline
\end{tabular}


APPENDIX B

FIGURE 1. Maureen's Identity and Nodal Point
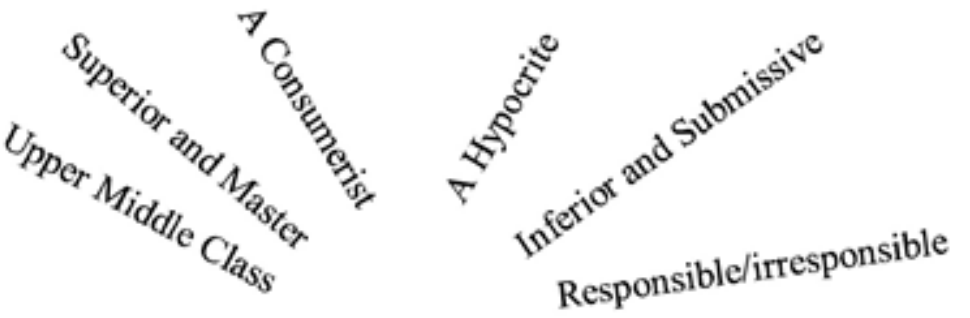

Ethical and Moral

Maureen

A Power Seeker

Materialistic and Possessive

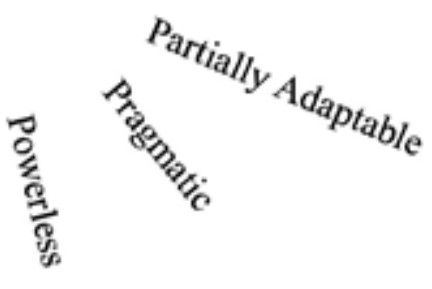




\section{APPENDIX C}

\section{The Utilized Soft Strategies by Bam and the Chief}

Among some discursive struggles Bam's discussion with the Chief has been selected to argue the strategies that they use in their conflicts. In chapter fifteen Bam is honestly telling the truth regarding the blacks gaining power and the war in the cities (JP 114) when suddenly the Chief begins to speak in English (Note: The brackets indicate the significations associated with specific signs and value signifiers):

[Chief:] And they want to kill you. [The Chief is highlighting the white's indeterminate locus.]-The chief spoke in English without any explanation and with a face that stopped short any show of surprise. [He is foregrounding his discourse through revealing his knowledge of English language.]

[Chief:] Those people from Soweto. They come here with Russias, those other ones from Moçambique, they all want take this country of my nation. Eh? They not our nation. [The chief is making polarization of we/they to define his nation in difference with other nations. He is constructing external antagonisms] ... If they coming, the government it's going give me guns...-You bring your gun and you teach how it's shooting [Chief is powerfully demanding.] (JP 143-145)

The discursive conflict continues, as Bam rationalizes and attempts to persuade the Chief logically to stop killing the black people, since Bam believes that the blacks "must not let the government make you kill each other. The whole black nation is your nation" (JP 147). In fact, Bam is pointing to nationalism as an element which has not changed into a moment in the discourse of African traditional life and culture which has tribalism as a prominent articulated concept in the master signifier. Based on Landau's clarifications, SA used to be a "world of tribes" and was governed through a vast range of customs rather than politics (1). Thereby, Bam's soft utilization of language turns out to be impractical, since the Chief overlooks his speeches regarding the significance of preserving the black unity via asking a question (Note: The brackets indicate the significations associated with specific signs and value signifiers):

[Chief:] You not got another kind, revolver? - The kind white men are known to keep in their bedrooms, to protect their radios and TV sets and coveted suits of clothing. [Through repeating his demands 
on guns and teasing materialism of the whites, the Chief is deconstructing the white's discourse via illuminating its weak points.]

[Bam:] I don't shoot people. [He values humanity. He honestly attempts to foreground his maxim to re-fix his nodal point.]

A short disgusted short from the black man; a back-wash of laughter. [The blacks are making fun of the white. Marginalization of the white discourse is continued.]

[Bam:] We're leaving now, time to go! (JP 147) [Bam does not continue the discursive struggle which attests his defeat and loss of power. It also bears the sign of his remaining resistance he has not approved the Chief's demand.]

The above example reveals how power is produced and reproduced between discourses. Here the utilized strategies are of a soft nature, since there are no severe reactions involved. While Bam strives to persuade the Chief by employing a logical and rational language as a soft tactic, the Chief's demanding speech and taunting talks neutralize Bam's efforts in foregrounding his discourse. Deconstruction of the opposing discourse is the next technique used in treating antagonisms. According to Torfing, as hegemony naturalizes the articulated objectivity in a discourse, deconstruction exposes the uncertainties and un-decidability of the other discourses (103). Likewise, Bam's discourse has been deconstructed as its weak points are revealed by the Chief and other black discursive practices. 